\title{
Analisis Sikap dan Pengetahuan terhadap Upaya Pencegahan Anemia pada Mahasiswa Bidan
}

\author{
Marlynda Happy Nurmalita Sari ${ }^{*}$, Dina Dewi Anggraini ${ }^{2}$ \\ ${ }^{1,2}$ Jurusan Kebidanan, Poltekkes Kemenkes Semarang \\ *Email: marlyndasari89@gmail.com
}

\begin{abstract}
Background: Midwife students are at risk of anemia, due to their busy life on campus and the influence of technology and modernization, thus ignoring the nutritional problems of the food they consume. Midwife students will later provide services to mothers and children so that sufficient knowledge is needed about health and healthy conditions without anemia. The purpose of this study was to determine the relationship between attitude and knowledge of midwife students to prevent anemi. Methods: analytical survey research type with cross sectional approach with a total sampling of 132 students of the Midwifery Study Program at the Blora Poltekkes Ministry of Health, Semarang. The research was conducted in September 2019 and data were collected by distributing questionnaires directly to students. Data analysis using Chi square. Results: There was a significant relationship between knowledge and efforts to prevent anemia with $p$ value $=0.001<0.05$. However, there is no significant relationship between attitudes and efforts to prevent anemia $p$ value $=0.164>0.05$. Good knowledge about anemia will be able to encourage these students to take preventive measures. Meanwhile, students who have a positive attitude towards anemia prevention efforts do not necessarily make efforts to prevent anemia due to economic and lifestyle factors. Conclusion: Midwife student knowledge related to efforts to prevent anemia and can be improved by providing more intense information with attractive media to midwife students. Meanwhile, attitude is not related to preventing anemia.
\end{abstract}

Keyword: anemia, attitude, efforts to prevent anemia, knowledge

\section{PENDAHULUAN}

Anemia pada remaja masih menjadi masalah kesehatan di Indonesia. Angka kejadian anemia masih tergolong tinggi terutama pada ibu dan remaja putri. (Setyaningsih, 2010). Data Riskesdas 2013 anemia pada remaja putri $37,1 \%$ mengalami peningkatan menjadi $48,9 \%$ pada Riskesdas 2018. Hal ini karena remaja putri mengalami proses menstruasi setiap bulan dan juga untuk pertumbuhannya serta kurang pengetahuan dalam pencegahan dan penanganan anemia (Depkes RI, 2018; Sumaryati, 2010).

Penelitian pada wanita di Kochi, Kerala bahwa anemia dianggap sebagai penyebab langsung 3-7\% dan penyebab tidak langsung 20-40\% kematian ibu. Mayoritas (72,6\%) dari 185 sampel menderita anemia. Di antara mereka, sebagian besar $(51,6 \%)$ adalah anemia ringan dan (21\%) mengalami anemia sedang.Ada hubungan yang signifikan 
antara sikap ibu dengan dengan status anemia ibu (Jose et al., 2016). Angka kematian ibu pada saat hamil dapat dicegah apabila pada saat remaja tidak mengalami anemia (Meidayati \& Purwati, 2017). Pemerintah sebenarnya sudah membuat himbauan bahkan kebijakan tentang pemberian tablet tambah darah pada remaja khususnya di SMP dan SMA, namun tingkat kepatuhannya masih rendah (Quraini, 2019) dan juga tentang pemenuhan gizi seimbang pada usia remaja untuk mencegah anemia (Rachmi, 2019).

Adanya perkembangan teknologi dan modernalisasi tidak serta merta dapat mengubah gaya hidup sehat pada kaum remaja. Justru mereka banyak mengabaikan pengetahuan yang mereka punya tentang nilai gizi yang baik dan seimbang dari perilaku apa yang mereka konsumsi. Sehingga timbul masalah kurangnya pemenuhan gizi terutama zat besi yang berakibat pada kejadian anemia (Meidayati \& Purwati, 2017). Remaja putri umumnya lebih memperhatikan penampilan, sehingga tidak jarang mereka melakukan diet dengan membatasi makanan atau adanya pantang makanan (Sumaryati, 2010). Bila makanan yang mereka konsumsi kurang maka banyak cadangan makanan terutama zat besi yang dibongkar akibatnya terjadinya anemia.

Adapun gejala anemia seperti lemah, letih, lesu, kelihatan pucat (baik kulit, bibir, gusi, mata, kulit kuku dan telapak tangan), saat beraktivitas ringan denyut jantung terasa kencang dan nafas pendek, nyeri dada, pusing, mata berkunang, cepat marah, tangan dan kaki dingin. Anemia yang tidak segera diatasi dapat menurunkan konsentrasi belajar yang berakibat pada penurunan akademik, dan juga kemampuan fisik karena untuk energinya di dapat dari konsumsi protein serta gangguan neurologi yang mempengaruhi kemampuan untuk memfokuskan perhatian (Caturiyantiningtiyas, 2016).

Mahasiswa masih tergolong dalam kelompok remaja yang beresiko terjadi anemia, tidak terkecuali mahasiswa kesehatan. Mahasiswa kesehatan dari segi pengetahuan tentunya lebih baik dibandingkan mahasiswa pada umumnya. Akan tetapi masih banyak ditemui mahasiswa kesehatan terutama bidan yang mengalami tanda dan gejala anemia. Hal ini mungkin dapat dipengaruhi karena kesibukan dalam mengerjakan tugas sehingga mengabaikan pemenuhan gizinya ataupun ketidaktahuan makanan sumber zat besi dan mungkin keadaan ekonomi karena tinggal dikos. Pengetahuan yang benar dan sikap yang positif tentunya akan dapat mencegah terjadinya anemia (Lestari, 2019). Upaya pencegahan anemia sejak dini (remaja) dengan kebiasaan hidup yang sehat akan dapat mengubah defiensi zat besi atau anemia saat dewasa nantinya (Yusoff et al., 2012).

Seseorang yang menderita anemia dapat dikarenakan karena kadar haemoglobin yang rendah. Penelitian pada remaja putri di SMK Negeri 1 Sukoharjo menunjukkan bahwa ada hubungan antara pengetahuan risiko anemia dengan kadar 
hemoglobin pada remaja putri dan tidak ada hubungan antara perilaku pencegahan anemia dengan kadar hemoglobin pada remaja putri (Hasyim, A. N., Mutalazimah, M., \& Muwakhidah, 2018). Penelitian lain yang dilakukan pada mahasiswi Kebidanan Salsabila Serang menunjukkan bahwa pengetahuan, sikap, status gizi dan frekuensi status makan yang berhubungan dengan anemia. Frekuensi makan merupakan variabel dominan yang berhubungan dengan kejadian anemia (Fairuza, 2018).

Berdasarkan penjelasan data tersebut bahwa dapat kita ketahui untuk penelitian anemia sudah banyak sekali dilakukan pada remaja putri di SMK maupun SMA sedangkan untuk mahasiswa kesehatan sendiri masih jarang dilakukan. Mahasiswa bidan mempunyai tugas mulia yang nantinya akan memberikan pelayanan kepada ibu dan anak sehingga dibutuhkan pengetahuan yang cukup tentang kesehatan dan kondisi sehat tanpa anemia. Mahasiswa dengan anemia akan terganggu dalam beraktiviatas dan berkonsentrasi sehingga diperlukan upaya pencegahan terhadap anemia. Tujuan penelitian ini untuk mengetahui hubungan antara pengetahuan dan sikap dengan upaya pencegahan anemia pada mahasiswa bidan.

\section{METODE PENELITIAN}

Jenis penelitian ini menggunakan metode survei analitik dengan pendekatan cross sectional. Sampel penelitian adalah mahasiswa Prodi DIII Kebidanan Blora Poltekkes Kemenkes Semarang berjumlah 132 mahasiswa tahun 2019 dengan metode pengambilan sampel menggunakan total sampling. Variabel pengetahuan, sikap dan upaya pencegahan diukur menggunakan kuesioner yang telah diuji validitas dan reliabilitasnya. Analisis univariat dengan distribusi frekuensi hanya untuk melihat karakteristik responden dan analisis bivariat menggunakan uji Chi-Squre.

\section{HASIL PENELITIAN}

Responden dalam penelitian ini adalah mahasiswa prodi DIII Kebidanan Blora dengan jumlah sampel 132. Adapun karakteristik responden dapat dilihat sebagai berikut :

Tabel 1. Karakteristik Responden Berdasarkan Pekerjaan Ibu dan Pekerjaan Ayah

\begin{tabular}{|c|c|c|}
\hline Karakteristik & Frekuensi (f) & $\%$ \\
\hline Pekerjaan Ibu & & \\
\hline Bekerja & 58 & 44 \\
\hline Tidak Bekerja & 74 & 56 \\
\hline Jumlah & 132 & 100 \\
\hline Pekerjaan Ayah & & \\
\hline PNS & 22 & 17 \\
\hline Karyawan Swasta & 21 & 16 \\
\hline Wirausaha & 46 & 35 \\
\hline
\end{tabular}




\begin{tabular}{lrc} 
Buruh & 32 & 24 \\
Tidak Bekerja & 11 & 8 \\
\hline Jumlah & $\mathbf{1 3 2}$ & $\mathbf{1 0 0}$ \\
\hline
\end{tabular}

Berdasarkan Tabel 1. sebagian besar wirausaha yaitu sebanyak $35 \% \quad$ (46 responden mempunyai ibu yang bekerja mahasiswa)., sedangkan yang paling yaitu sebanyak 56\% (74 mahasiswa). sedikit tidak bekerja/ pensiun yaitu $8 \%$ Sedangkan untuk pekerjaan ayah (10 mahasiswa). responden sebagian besar adalah

Tabel 2. Karakteristik Responden Berdasarkan Umur, Umur Menarche dan Lama Haid

\begin{tabular}{lccccc}
\hline & Mean & Median & SD & Min & Max \\
\hline Umur & 19,79 & 19 & 5,58 & 17 & 23 \\
Menarche & 12,82 & 13 & 1,27 & 10 & 16 \\
Lama haid & 7,12 & 7 & 1,15 & 4 & 11 \\
\hline
\end{tabular}

Berdasarkan Tabel 2. hasil penelitian Sedangkan umur menarche responden menunjukkan bahwa rata-rata umur berkisar 10 - 16 tahun dengan lama haid responden berkisar $17-23$ tahun. berkisar $4-11$ hari.

Tabel 3. Hubungan Sikap dengan Upaya Pencegahan Anemia

\begin{tabular}{lcccc}
\hline & \multicolumn{3}{c}{ Upaya Pencegahan } & \multirow{2}{*}{-value } \\
\cline { 2 - 4 } & \multicolumn{2}{c}{ Kurang } & Baik & \\
Sikap & & & & 0,164 \\
Negatif & 37 & $(56,9 \%)$ & $28(43,1 \%)$ & \\
Positif & 29 & $(43,3 \%)$ & $38(56,7 \%)$ & \\
\hline
\end{tabular}

Berdasarkan hasil analisis, dari tabel 3. menunjukkan bahwa responden yang mempunyai sikap negatif terdapat $56,9 \%$ (37 mahasiswa) mempunyai upaya pencegahan anemia kurang, sedangkan responden yang bersikap positif terdapat $56,7 \%$ (38 mahasiswa) mempunyai upaya pencegahan anemia baik. Berdasarkan hasil chi square didapatkan nilai $\mathrm{p}$ value $=$ $0,164>0,05$, sehingga dapat disimpulkan bahwa tidak ada hubungan antara pengetahuan dan sikap dengan upaya pencegahan anemia. 
Tabel 4. Hubungan Pengetahuan dengan Upaya Pencegahan Anemia

\begin{tabular}{lcccc}
\hline & \multicolumn{2}{c}{ Upaya Pencegahan } & \multirow{2}{*}{ CI-95\%, OR } & \multirow{2}{*}{$\boldsymbol{p}$-value } \\
\cline { 2 - 3 } & Kurang & Baik & & \\
Pengetahuan & & & & \\
Kurang-Cukup & $18(85,7 \%)$ & $3(14,3 \%)$ & $2,193-28,28$ & 0,001 \\
Baik & $48(43,2 \%)$ & $63(56,8 \%)$ & $($ OR 7,87$)$ & \\
\hline
\end{tabular}

Berdasarkan hasil analisis, dari tabel 4, menunjukkan bahwa responden yang berpengetahuan kurang-cukup terdapat 85,7\% (18 mahasiswa) mempunyai upaya pencegahan anemia yang kurang, sedangkan responden yang berpengetahuan baik terdapat 56,8\% (63 mahasiswa) mempunyai upaya pencegahan anemia yang baik. Berdasarkan hasil chi square didapatkan nilai $\mathrm{p}$ value $=0,001<0,05$, sehingga dapat disimpulkan bahwa ada hubungan antara pengetahuan dengn upaya pencegahan anemia. Dengan nilai OR 7,87 , sehingga remaja putri yang mempunyai pengetahuan yang baik 7,8 kali lebih baik dalam upaya pencegahan anemia dibandingkan yang pengetahuannya kurang-cukup.

\section{PEMBAHASAN}

Berdasarkan hasil analisis univariat didapatkan bahwa rata-rata umur mahasiswa bidan adalah 19 tahun, ini masih termasuk dalam kategori usia remaja dan dianggap sudah mengenal dan mengetahui anemia zat besi. Dengan demikian remaja putri dapat menjawab kuesioner pengetahuan dan sikap terhadap pencegahan anemia. Untuk usia menarce masih dalam batas normal yaitu rentang 10 - 16 tahun. Perbedaan usia menarce pada remaja putri karena pengaruh hormon yang berbeda disetiap individu. Berdasarkan pekerjaan orang tua, sebagian besar ayah responden bekerja sebagai wirusaha $35 \%$ dan ibu tidak bekerja 56\%. Sebuah penelitian di Sekolah Menengah Quazvin menunjukkan bahwa tingkat pendidikan, usia, pekerjaan ayah dan ibu, pekerjaan memiliki hubungan yang signifikan dengan pengetahuan tentang anemia. (Shojaeizadeh, 2001). Oleh karena responden homogen yaitu mahasiswa kesehatan (bidan) yang rata-rata umurnya hampir sama sehingga tingkat pengetahuan antar responden tidak jauh berbeda. Dari segi pekerjaan orang tua baik ayah maupun ibu tentunya akan berpengaruh terhadap makanan yang dikonsumsi oleh mahasiswa yang akan berpengaruh terhadap upaya pencegahan anemia.

Berdasarkan hasil analisis bivariat didapatkan bahwa pengetahuan berhubungan dengan upaya pencegahan anemia dengan $p$ value $0,001<0,05$ hal 
ini sejalan dengan penelitian yang dilakukan di SMA Negeri 1 Polokarto Kabupaten Sukoharjo dengan p value 0,03 dan RP 0,81 bahwa ada hubungan tingkat pengetahuan dengan kejadian anemia (Caturiyantiningtiyas, 2016). Penelitian di Pondok Pesantren Wilayah Jenu Kabupaten Tuban, dimana remaja putri yang mempunyai pengetahuan yang baik maka akan semakin baik juga upaya pencegahan terjadinya anemia terutama saat menstruasi (Lestari, 2019). Menurut Notoatmojo (2012) pengetahuan merupakan hasil tahu dan terjadi apabila seseorang sudah melakukan penginderaan pada suatu objek. Pengetahuan merupakan unsur yang penting dalam seseorang melakukan tindakan atau keputusan.

Faktor yang mempengaruhi pengetahuan sesorang adalah informasi baik melalui media massa atau dari petugas kesehatan (pendidikan kesehatan). (Meidayati \& Purwati, 2017; (Kusuma, N.I. dan Kartini, 2015). Mahasiswa bidan nantinya akan memberikan pelayanan kepada ibu dan anak sehingga dibutuhkan pengetahuan yang cukup tentang anemia maupun upaya pencegahan anemia. Mahasiwa bidan yang mempunyai pengetahuan yang baik tentang anemia yang didapatkan dari sumber informasi dari ahlinya/ pakarnya maupun media massa pasti akan mengetahui bagaimana melakukan upaya pencegahan anemia dengan baik. Hal ini karena mereka mengetahuai bahaya atau dampak dari anemia bagi kesehatannya dan bagaimana cara mencegah anemia itu sendiri.

Hasil analisis bivariat antara sikap dengan upaya pencegahan anemia tidak terdapat hubungan yaitu $\mathrm{p}$ value $0,164>$ 0,05 . Hal ini berbeda dengan penelitian yang dilakukan di SMA Negeri 1 Polokarto bahwa ada hubungan antara sikap remaja putri dengan kejadian anemia $\mathrm{p}$ value $=0,03$ dengan $\mathrm{RP} 1,22$ (Caturiyantiningtiyas, 2016). Begitu juga berbeda dari penelitian yang dilakukan di kota Pekalongan bahwa ada hubungan yang bermakna antara sikap ibu dengan praktek ibu dalam pencegahan anemia gizi besi $p$ value $=0,028$ (Setyaningsih, 2010) . Menurut (Lestari, 2019) bahwa remaja putri yang mempunyai sikap positif akan semakin baik juga upaya pencegahan terhadap terjadinya anemia besi. Menurut Notoatmojo (2012) bahwa sikap belum merupakan tindakan akan tetapi merupakan presdiposisi tindakan suatu perilaku. Sikap seseorang sangat berkaitan dengan pengetahuan yang mereka miliki. Proses pembentukan sikap sendiri dimulai secara bertahap dimulai dari proses belajar. Perubahan sikap dipengaruhi oleh rangsangan atau komunikasi (seperti diperhatikan dan dipahami) sehingga timbul respon positif (Kusuma, N.I. dan Kartini, 2015).

Dalam penelitian ini tidak ada hubungan antara sikap dan upaya pencegahan anemia pada remaja putri hal ini karena remaja yang mempunyai sikap positif belum tentu mau melakukan upaya pencegahan anemia, hal ini karena pengaruh modernisasia atau gaya hidup dan belum adanya kesadaran dalam diri remaja sendiri (Chintia Risva \& Zen Rahfiludin, 2016). Faktor yang 
berhubungan dengan upaya pencegahan anemia tidak hanya sikap akan tetapi dapat dipengaruhi oleh faktor yang lain (eksternal) misalnya faktor keluarga. Walaupun remaja sudah mempunyai sikap positif akan tetapi apabila ekonomi keluarga tidak mendukung maka tidak akan ada upaya pencegahan anemia (Setyaningsih, 2010). Penelitian di Delhi, menunjukkan bahwa remaja mempunyai pengetahuan tentang anemia tetapi tidak memiliki sikap dan perilaku yang memadai dalam prakteknya. Perbanyakan pengetahuan gizi yang komprehensif tentang makanan dan suplemen yang kaya pada besi wajib dibuat (Singh et al., 2019).

Mahasiswa bidan yang mempunyai sikap positif terhadap upaya pencegahan anemia belum tentu mau melakukan upaya pencegahan anemia, hal ini karena latar belakang pekerjaan orang tua. Orang tua mahasiswa bervariasi pekerjaaannya dengan penghasilan berbeda yang akan berdampak pada makanan yang dikonsumsi mahasiswa dalam upaya pencegahan anemia. Di samping itu, di zaman modern dan pengaruh teknologi akan mempengaruhi gaya hidup seperti banyak sekali makanan junk food dan gorengan yang sedikit sekali kandungan gizinya yang biasanya lebih banyak dikonsumsi dan lebih disukai oleh mahasiswa, sehingga bisa kemungkinan lebih beresiko terjadi anemia. Selain itu karena kesibukan dari mahasiswa bidan walaupun mereka mempunyai pengetahuan yang baik tentang anemia dan upaya pencegahannya belum tentu mereka mempunyai sikap yang positif terhadap upaya pencegahan anemia karena tidak adanya waktu dan akses untuk mengkonsumsi makanan yang bergizi yang banyak mengandung zat besi.

\section{KESIMPULAN DAN SARAN}

Pengetahuan berhubungan secara signifikan dengan upaya pencegahan anemia pada mahasiswa bidan. Sedangkan sikap mahasiswa bidan tidak berhubungan dengan upaya pencegahan anemia. Perlunya pendidikan kesehatan atau pemberian informasi yang lebih intens dengan media yang menarik kepada mahasiswa bidan agar dapat memberikan kesadaran secara bertahap pada mahasiswa bidan sehingga timbul upaya pencegahan anemia.

\section{DAFTAR RUJUKAN}

Caturiyantiningtiyas, T. (2016). Hubungan Antara Pengetahuan, Sikap dan Perilaku dengan Kejadian Anemia Remaja Putri Kelas X dan XI SMA Negeri 1 PoloKarto [Ilmu Kesehatan Masyarakat, Fakultas Ilmu Kesehatan, Universitas Muhammadiyah Surakarta]. http://eprints.ums.ac.id/39689/1/nas kah publikasi.pdf

Chintia Risva, T., \& Zen Rahfiludin. (2016). Faktor-Faktor Yang Berhubungan Dengan Kebiasaan Konsumsi Tablet Tambah Darah Sebagai Upaya Pencegahan Anemia Pada Remaja Puteri (Studi Pada Mahasiswa Tahun Pertama Di 
Fakultas Kesehatan Masyaratak Universitas Diponegoro). Jurnal Kesehatan Masyarakat (JKM), 4, 2356-3346.

http://ejournal-s1.undip.ac.id/index. $\mathrm{php} / \mathrm{jkm}$

Depkes RI. (2018). Pesan Untuk Remaja Putri Indonesia: Cantik Itu Sehat, Bukan Kurus. https://www.kemkes.go.id/article/vie w/18112300003/pesan-untuk-remaja -putri-indonesia-cantik-itu-sehat-bu kan-kurus.html

Fairuza, F. (2018). Hubungan Pengetahuan, Sikap, Status Gizi Dan Frekuensi Makan Dengan Anemia Pada Remaja Putri Di Akademi Kebidanan Salsabila Serang. Jurnal Ilmiah Kesehatan Delima, 2, 34-42. http://ejournal.stikessalsabilaserang. ac.id/index.php/JIKD/article/view/2 $5 / 17$

Hasyim, A. N., Mutalazimah, M., \& Muwakhidah, M. (2018). Pengetahuan Risiko, Perilaku Pencegahan Anemia dan Kadar Hemoglobin pada Remaja Putri. Profesi (Profesional Islam): Media Publikasi Penelitian, 15(2), 28-33. http://ejournal.stikespku.ac.id/index. $\mathrm{php} / \mathrm{mpp} /$ article/view/28/183

Jose, S., Antony, S. C., \& Isaac, B. R. (2016). International Journal of Multidisciplinary and Current Research Impact of Knowledge,
Attitude and Practice on Anemia status among women in coastal Kochi, Kerala. J. of Multidisciplinary and Current Research, 4, 295-298. http://ijmcr.com

Kusuma, N.I. dan Kartini, F. (2015). Pengaruh Pendidikan Kesehatan Anemia Pada Remaja Putri Terhadap Tingkat Pengetahuan Dan Sikap Dalam Mencegah Anemia Pada Siswi Kelas X SMA Muhammadiyah 5 Yogyakarta [Universitas Aisyah Yogyakarta]. http://digilib.unisayogya.ac.id/id/epr int/1132

Lestari, D. I. . (2019). Analisis Faktor Yang Berhubungan Dengan Upaya Pencegahan Anemia Saat Menstruasi Pada Remaja Putri Di Pondok Pesantren Wilayah Jenu Kabupaten Tuban [Universitas Airlangga]. http://repository.unair.ac.id/id/eprint/ 84400

Meidayati, R. D., \& Purwati, Y. (2017). Pengaruh Penyuluhan Kesehatan Tentang Pencegahan Anemia Terhadap Sikap Dalam Pencegahan Anemia Pada Remaja Putri Di SMA Negeri 1 Yogyakarta 1. http://digilib2.unisayogya.ac.id/xml ui/handle/123456789/1717

Quraini, D. F. (2019). Sikap, Norma Subjektif, dan Kontrol Perilaku 
dengan Niat Patuh Konsumsi Tablet

Tambah Darah sebagai Upaya Pencegahan Anemia pada Remaja. https://repository.unej.ac.id/bitstrea m/handle/123456789/92590/Diana

Febriyanti

Quraini-142110101098.pdf?sequenc $\mathrm{e}=1$ \&isAllowed $=\mathrm{y}$

Rachmi, C. N. D. (2019). Aksi Bergizi, Hidup sehat Sejak sekarang Untuk Remaja Kekinian. Kementrian Kesehatan Republik Indonesia.

Setyaningsih, S. (2010). Pengaruh Interaksi, Pengetahuan Dan Sikap Terhadap Praktek Ibu Dalam Pencegahan Anemia Gizi Besi Balita Di Kota Pekalongan Tahun 2008 [Universitas Diponegoro]. http://eprints.undip.ac.id/18320/

Shojaeizadeh, D. (2001). A Study on Knowledge, Attitude and Practice of Secondary School Girls in Qazvin on Iron Deficiency Anemia. In Health (Vol. 30, Issue 2). https://www.sid.ir/en/journal/ViewP aper.aspx $? \mathrm{ID}=33488$

Singh, M., Rajoura, O. P., \& Honnakamble, R. A. (2019). Anemia-related knowledge, attitude, and practices in adolescent schoolgirls of Delhi: A cross-sectional study. International Journal of Health \& Allied Sciences, $8(2)$, 144-148. https://doi.org/10.4103/ijhas.IJHAS
-97_18

Sumaryati, N. (2010). Pengaruh Intervensi Buklet Info Anemia Gizi Dalam Pencegahan Dan Penanggulangan Anemia Gizi Terhadap Pengetahuan dan Sikap Siswi Sekolah Menengah Umum Di Kabupaten Demak [Universitas Diponegoro].

http://eprints.undip.ac.id/14363/

Yusoff, H., Nudri, W., Daud, W., \& Ahmad, Z. (2012). Nutrition Education And Knowledge, Attitude And Hemoglobin Status Of Malaysian Adolescents. In $J$ trop Med public health (Vol. 192, Issue 1).

https://d1wqtxts1xzle7.cloudfront.ne t/35380539/hb_status.pdf?14149555 $84=\&$ response-content - disposition $=\mathrm{i}$ nline $\% 3 \mathrm{~B}+$ filename $\% 3 \mathrm{DS}$ SoutheaSt aSian_J_trop_Med_public_health.pd f\&Expires $=1595124494 \&$ Signature $=$ KSLNYhZq3NsVU-P5oOUplVdU gLIpk7UbmrcuMhV 7TWx-QnVF3 z7rhzPIF 